\title{
PERILAKU PENOREHAN RANGGAH PADA TUMBUHAN OLEH RUSA BAWEAN (Axis kuhlii)
}

\author{
Gono Semiadi*, Kustoto*, I Ketut Sutama**, Burhanudin Masyud ${ }^{* * *}$ \\ *Puslitbang Biologi, Balitbang Zoologi-LIPI Bogor, "*Balitnak-Ciawi Bogor, \\ ***Fak.Kehutanan-IPB, Dermaga Bogor
}

\begin{abstract}
The behavior of antier rubbing in the Cervidae family during the period of hard antlers is related to the territorial marking and reproductive activity. Bawean deer (Axis kuhlii) is one of the rarest animals in Indonesia and endemic to Bawean Island. The knowledge of their biology in their natural habitat is scarce. The objective of this study is to understand on their behavior, particularly the stags during their hard antlers period by observing their rubbing activities on the plantations in their natural habitat. Data collections were conducted in four sites, from June 1996 to October 1996, through monthly visits. Transects with the length of 900 to $2000 \mathrm{~m}$ and width of $100 \mathrm{~m}$ were established. Observations took place every $100 \mathrm{~m}$ along the transects in both sides on the area of $25 \mathrm{~m}^{2}$. The name of local plants which were rub was noted, the length and width of the rubbing marks on the plants and the diameter of the plants were measured. The results showed there were 22 species (in which 7 were unidentified) of plants being rub by the deer. The highest intensity is on Macu (15\%) followed by Ngos-ngosan and Sentol (11\% each). Number of deaih plants due to rubbing activity was very low $(<1 \%)$. Mean of the plants diameter being rub was $19.1 \mathrm{~mm}$, with the length and total area being rub were $19.1 \mathrm{~mm}$ and $6521 \mathrm{~mm}^{2}$, respectively: From this study it can be concluded that stags rub the plants during their hard antlers period on the bushy type category. The rutting season for Bawean stags in their habitat was estimated between May to November.
\end{abstract}

Key words: Bawean deer, Axis kuhlii, antler rubbing, rutting. 